\title{
Strategies Used in Changing and Correcting Student Misbehaviors in Classrooms regarding Evaluation of Teachers of Secondary Education
}

\author{
Gülçe Düzey, Çağda Kivanç Çağanağa \\ European University of Lefke, Lefka, North Cyprus \\ Email: gulceduzey@gmail.com, ckivanc@eul.edu.tr
}

How to cite this paper: Düzey, G. and Çağanağa, Ç.K. (2017) Strategies Used in Changing and Correcting Student Misbehaviors in Classrooms regarding Evaluation of Teachers of Secondary Education. Open Access Library Journal, 4: e3532. https://doi.org/10.4236/oalib.1103532

Received: March 16, 2017

Accepted: August 5, 2017

Published: August 8, 2017

Copyright $\odot 2017$ by authors and Open Access Library Inc.

This work is licensed under the Creative Commons Attribution International License (CC BY 4.0).

http://creativecommons.org/licenses/by/4.0/

\section{c) (i) Open Access}

\begin{abstract}
The aim of this study is to identify student misbehaviors in the classroom and to determine the strategies, which can be used to change these behaviors. The population of the study is the secondary education teachers who work at Güzelyurt Region between 2015-2016. The sample of the study is based on three secondary education teachers, who were chosen by random sampling method. One on one interviews were held and and pre-arranged questions were directed to the chosen teachers. In the light of answers received, both the definition of undesired behaviors and what methods and ways teachers utilize were discovered. The undesired behaviors that teachers encounter in the classroom are: talking during class, showing without books and notebooks, bringing phones to the class, switching seats without permission, not paying attention to the class, situations arising from being disturbed by each other. The strategies teachers use for undesired behaviors in the class are: warning, making agreements with the students, dealing rewards or punishment, establishing eye contact, appointing tasks, sending them to the guidance services or the principle.
\end{abstract}

\section{Subject Areas}

Education

\section{Keywords}

Teacher, Classroom Management, Misbehavior, Strategies of Changing Misbehaviors

\section{Introduction}

Education is a collective of processes that goes on from the birth of an individual 
until they die in which one develops their attitude and behaviors in a society. Education is a process by which an individual chooses a path leading to a goal using their own life experience through positive behavioral changes take place [1]. Education begins in the family and continues progressively in school and, later, during one's career. Although nature has a great impact on a person's life and behaviors, school also has a huge impact on an individual's behaviors. Having a connection with the environment, school is an educational center where students spent the majority of their time. So, it is inevitable for students to be affected by physical and social conditions arising in school. Classrooms are the places where a student who attends school receives their planned and scheduled education. This is why, while the physical conditions of a classroom are important, the responsibility on teachers is great. Because, teachers are the ones who maintain order in the class and manage it. Classrooms are places in which students and teachers with different personal traits from different backgrounds and tools and resources required for education are gathered. Classroom management is maintaining the environment and order required for the optimum learning conditions by determining class rules, establishing an order in the class, managing class subjects and time efficiently and keeping student behaviors in check.

Students complete most of the yearly learning process in the classrooms. During this process, students' adopting desired behaviors and the education to be given effectively are directly related to the physical ans psychological conditions of the classrooms. It is the teacher, who will create the physical and psychological environments and maintain it under control. Teachers to have a developed sense of responsibility, be able to access the correct information and convey it in an effective manner, have strong communication and problem solving skills are complementary to this process. Depending on class management quality, individuals who are equipped with needs of recent society.

The main goal of classroom management is to create the optimal environment for realization of planned goals. Another important aim else than this is efficient time management in the classroom. It is difficult for a student to listen to the lecture quietly. Due to this reason, it is very important to manage the time which is set for the lecture efficiently, to focus the student to understand and persuade to listen the lecture. Another aim, which has remarkable role in classroom management is to set class rules [2]. Rules are a whole of principles that lead our behaviors in every aspect our life as well as the classroom. Rules that evoke positive behaviors and are based on desired behaviors ensure the sustainability of the classroom order and an effective communication between teachers and students. In an effectively managed classroom, more time is spent on learning activities and students participation to the class is increased. Thus, increase of success is ensured for students [3]. So, a contemporary class management system that is student based is developed.

Contemporary classroom management is a method that takes students' cog- 
nitive and sensory development into account and through whihch teachers develop an effective educational environment and consider individual needs of students [4]. In a classroom that is managed using this method, self realization of students are supported. In this context, our society needs bringing up teachers equipped with such qualities [5].

\subsection{Teachers, Teachers' Role and Becoming a Role Model Concerning Classroom Management}

Teachers are people who shape personality of a society, aid in gathering knowledge, take responsibility for us in an early age and prepare us to life in the best way they can. As children grow, teachers satisfy our need of gathering knowledge in a planned and scheduled manner. Changing of ages, developing technology and the modern education system that progresses everyday have increased the need for teachers who observe the developments closely. In this light, it is important for teacher to be trained properly and be monitored during their service career. Besides knowledge, skills, attitude and general knowledge, there are important qualities a teacher must possess. The most important of these is for a teacher to be developed as a person and is self confident. Because, teachers are people who become character examples and are role models to people in their lives. Another quality for teachers is to be highly empathetic. They need to be able to put themselves in their students' shoes and be sensitive towards the needs of people they are dealing with. A minor connivance in an individual's education may cause a major mistake. That mistake will not only harm the individual that is brought up but also the society. In this light, teachers need to understand the gravity of their duty and need to be people with sense of responsibility [6]. Teachers who have strong communication skills, care about their relations, are people of action and inquisitor $y$ by nature will do their jobs adequately. According to a Japanese philosophy, a teacher's role is as follows: A society that can have a use an educated individual is one that is rational, civilized and advanced. However, a society that elects the best of adult individuals to be teachers a strong society. There is a direct link between a strong society and strong individuals.

\subsection{Undesired Behavors in the Classroom Their Reasons}

Needs, expectations, level of preparedness, learning speed, studying methods, attitudes, habits, emotions and family lives of students in a classroom vary. These variations cause different behaviors in the classroom [7]. Should these behaviors affect the classroom negatively and hinder the educational efforts, they are called undesired behaviors. Undesired behaviors are classified depending on the problems they bring with them. These are; the behavior to prevent the student exhibiting it or other students from learning, put the student exhibiting it or other students in physical danger, harming school's or fellow students' property, preventing the student exhibiting the behavior from communicating with other students [8]. 
These behaviors are caused by many factors within and without the classroom [9]. The most important factor outside of the class is a student's family life. Tolerant or oppressive household attitudes impact the student's behaviors greatly. Another out of the classroom factor is the environment in which the student resides. The environment is places around the school and where students spend time after school. School's atmosphere, location and social areas in which the student spends time after school have a huge impact on a student's behaviors. In addition to aforementioned, whether the school is a democratic place, communication among parents, school and teachers is strong are also also determining factors in a student's behaviors. The most important elements within the classroom are the features of teachers and students. Personal traits of the teacher, their vocational knowledge and classroom management capabilities as well as a student's personal traits determine what the behaviors shall be. The physical condition of the classroom is also important. The physical condition of the classroom has positive or negative effects on a student's motives and behaviors. If the elements such as desks, chairs, cupboards, distance between the teacher and students, lighting, temperature, sound and colors are poorly arranged, student behaviors are affected negatively. Another in-class element that affects students' behavior is the current educational plans and schedules. Planning, arranging educational environment, creating study groups are elements that increase academic success. Ensuring such elements depend on how well the plans are prepared [7].

\subsection{Strategies on Preventing an Altering Undesired Behavior}

In order to prevent undesired behavior, the behavior must be defined and the method to be utilized to change this behavior must be decided. In order to change an undesired behavior to a desired one, one of many different attitudes and choices may be picked and student will be made to adopt the correct behavior [10]. While practicing this, knowledge, experience and patience from the teacher are crucial. Strategies for preventing and altering undesired behaviors are as follows.

Eye contact: Eye contact enables individuals to communicate without words, so, it is possible to communicate through looks. Teachers may convey that they don't approve of the behavior and the student should stop the behavior by establishing eye contact with the student who exhibit the undesired behavior. While through this method the class isn't interrupted, other students realizing the problem causes negative outcomes [11].

Asking questions: Teachers aim to recover a student's attention who exhibits undesired behavior, on the subject by asking questions related to the subject. The student pays attention to the subject in order to be able to be prepared to answer the questions and so, the undesired behavior is prevented [11].

Warning the class: It is a teacher's expressing their disapproval gradually, depending on the undesired behavior. Firstly, the teacher should express their 
disapproval of the undesired behavior through body language. If the behavior persists, other methods may be developed. For example; eye contact may be established or make a gesture with their finger, asking the student to be quiet. Should these methods prove ineffective, the message may be conveyed through phrases such as "silence, please." Students' behaviors are corrected without reprimanding and efficiency of the lecture is maintained by doing so [2].

Personal warning: Teacher calls the name of the student who is exhibiting the undesired behavior and interrupts the undesired behavior. The student is reminded what the desired behavior is and told about the outcome of the undesired behavior. Followed by changing the undesired behavior, the teacher may express that he/she is aware of the positive behavior to reinforce the behavior.

Indifference: Students exhibit undesired behaviors and actions in order to seek attention or interrupt the lecture. Teachers to ignore such undesired behaviors may lead students to stop the undesired behavior and pay attention to the lecture [11].

Ignoring: This strategy may be utilized for preventing the undesired behavior from standing out. This way, the undesired behavior isn't set as an example to other students and the student won't persist on the undesired behavior seeing that the teacher isn't reacting. The magnitude of the behavior is important while utilizing this strategy. Because the behavior may be the kind that can't be ignored. Unless such behaviors are stopped soon, problems may get worse [4].

Understanding the problem: In order to understand the cause for the undesired behavior is the most basic step towards altering the behavior. Determining the cause of the behavior is crucial to prevent bigger problems that may occur later. While determining the the undesired behaviors, students' personal features (age, gender, family structure, environment, etc.) and the physical condition of the classroom are considered [4].

Physical change: Should the undesired behavior persist despite warning the student, the teacher may seat the student exhibiting the undesired behavior to the front, the back of the class or anywhere that is favorable to the teacher. If there are 2 or more students exhibiting the undesired behavior, the teacher dissolve the group and ask them to sit separately. Teachers send the students out of the classroom because they upset the classroom order, on occasion. In cases that students don't desire to be in the lecture, such action is a reward. Also, this is not allowed by the administrations [11].

Allocating responsibility: Being allocated responsibility triggers an individual's sense of responsibility. By allocating responsibility to the students, it is ensured that the student will stop the undesired behavior and pay attention to the given task. Furthermore, they will feel trustworthy, superior and helping and be more interested in the lecture. The responsibilities that could be allocated to the students should be manageable tasks such as: helping with using class materials, summarizing, writing reports, collecting homeworks, making social 
activity announcements.

Talking to the student: If the student refuses to alter the behavior despite utilization of various strategies, they need to be talked to and made aware. This talk should be given in the classroom without putting the individual under spotlight and in a manner and at the right times, such as when other students can listen and benefit from the speech.

Directing towards the correct behavior: The teacher approaches to the student, refraining from verbal warning, aiming to dissuade the student from the behavior. For example, when a student keeps making noise by knocking pen or pencil on the desk, approaching the student, taking the tool and placing it on the desk makes the student to stop the behavior [11].

Making changes in the lecture: Teachers constantly using the same methods, rendering themselves active and students passive will cause the lecture to be boring and students to be distracted. It is inevitable for distracted students to act out. So, the undesired behaviors that may occur may be prevented by making changes in the lecture, teaching methods and tools [2].

Communicating with the School Management, Counseling Services and Family: In cases which the undesired behavior persists, the teacher; cooperates with school administration and counseling services to examine the behavior. A plan is made for the resolution process of the behavior. In order for the plan to run most effectively, the family should know about the situation. The problem must be solved as quickly as possible with support from family and a professional approach [4].

Punishment: Academicians keep the students from enjoyable things in order to prevent undesired behaviors. Once other methods are utilized and no positive alteration on the behavior is seen, punishments are utilized. Before the punishment is commenced, the student must know what punishment they are to receive from which behavior. It is impossible for a student who doesn't know why they are punished to exhibit desired behaviors. The punishment must fit the crime and should be appropriate for students' age, gender, psychological and physical development. Although punishment are seen as adventitious for ingraining in desired behaviors, disadvantages should also be considered. For example, if there's a probability of the punished student to develop resentment or hatred towards the teacher; the students develops fear of the teacher; or increase anxiety, learning process may be hindered [2].

\subsection{Approaches for Altering Undesired Behaviors}

Humanistic Approach: This approach is based on believing in and trusting the student. Student is well-meaning and is provided with an environment in which they will feel free. In this approach, the student is not judged and student is talked to directly for eliminating the undesired behavior; feelings and opinions are expressed [11].

Negotiation Approach: In this approach, everything is mutual. Any student 
exhibiting an undesired behavior is warned immediately by the teacher. Thus, the consequence of the undesired behavior is realized. So, the undesired student behavior is prevented [11].

Correcting the behavior approach: Various strategies are utilized depending on the undesired behavior [11]. These are:

Observing the misbehavior: Through this strategy, the teacher pinpoints what the undeserved behavior is. So, altering the undesired behavior becomes an easier process.

Reinforcing: Teacher reinforces a student's desired behavior, ensuring its permanence and sustainability. While doing so, choosing which reinforcement for which behavior is to be done carefully.

Eliminating: Negative reinforcement is used on the student in order to eliminate the undesired behavior. Using the negative reinforcement immediately after the behavior helps achieve the goal more easily.

Agreeing: In this strategy, common ground between the teacher and student is established. However, the teacher requires that their own terms are met first. For example, "should students listen to the lecture silently, they can have a fun activity until the break." Thus, an agreement between the teacher and students is achieved.

Accepting desired behaviors: Graining in the desired behavior to the student should be made a process. It is not easy to impose the positive behavior to the student at the first try. In this case, spreading the process of graining in the desired behavior to the student over time is more efficient. For example, a class with noise problem can't listen to the lecture in silence. In he beginning, they should be made to stay silent for 10 minutes and the amount should be increased through time [2].

3.6 Returning to lecture. The teacher should prefer to return to the lecture in order to cut the undesired behavior short. Focusing on the undesired behavior during class may have negative effects. By resuming the lecture, students stop the undesired behavior [2].

\section{Methodology}

\subsection{Model of the Study}

This research is a qualitative study which analyzes the strategies utilized in order to alter undesired student behaviors during class and correct them, in the light of assessments done by middle school teacher. Qualitative study is the process of gathering and analyzing data in a planned and systematic manner in order to seek reliable solutions on one problem and assessing it upon interpreting. Research is an effort to search, learn, render the unknown, known [12].

While determining in which schools the research to be conducted, density and easy access sampling methods are utilized from purposeful sampling methods.

\subsection{Population and Sampling of the Research}

Population of the research is, middle school teachers in Güzelyurt region during 
2015-2016 academic year. Sampling of the research were determined among the teachers working for the schools. One teacher from each school were included in sampling. The teachers included in sampling were determined through random sampling method.

\subsection{Data Collection Tool}

In this research, questions were prepared by the researcher that could determine the strategies which could be utilized to alter and correct undesired student behaviors in the classroom. Standardized open-ended interviewing method was used as data collection method. The prepared questions were directed systematically, in proper order. However, while the order is followed, flexibility is allowed to ensure more efficient interviews. Interviews were held for approximately 20 minutes. For data analysis, firstly, the handwritten interview notes were typed and the data gathered was categorized.

Three open-end questions were asked on the interview form.

How do you gain classroom management?

What are the misbehaviors in the classroom?

What are the strategies that you use in the classroom for changing misbehaviors?

Participants of the research comprise of 2 high school and 1 middle school teachers working in city center of Güzelyurt. In the study, schools are displayed as school 1, school 2 and school 3 while each teacher chosen from each school are displayed as teacher 1 , teacher 2 , teacher 3 .

This research aimed to determine results through asking 3 questions to 3 teachers working at 3 different middle schools on undesired classroom behaviors.

\section{Findings}

This section of the research consists of the data acquired by way of interviewing. How do you manage your classes?

Teacher 1: The school rules are determined on the first day of school, I come to the class prepared, I adjust the tone of my voice according to the student state and importance of the subject is stressed; achieving class management.

Teacher 2: The class rules are established on the first day of school, rule breakers are punished proportionately to their fault, lectures are made interesting for the students; achieving class management.

Teacher 3: Mutual ground is found with students, class order is established, active participation is expected, students are made to observe the rules; achieving class management.

What defines the undesirable classroom behavior?

According to Teacher 1, undesirable behaviors are communication among students, changing seats without leave, showing up without books and notebooks, using cellphones, not taking notes. 
According to Teacher 2, the most undesirable behaviors are, asking unnecessary questions in order to interrupt the class, students talking among each other during class, disturbing each other, fighting among them.

According to teacher 3, the most common undesirable behaviors are tardiness, arrogant behavior, speaking out of turn, asking to leave class with excuses such as going to the bathroom, speaking rudely to classmates.

What strategies do you use to change these behaviors?

Teacher 1: Student who doesn't pay attention and constantly speaks is seated separately. Students who play on their cellphones without paying attention to class and distracting other students are relived from their phones and it's not given back until the end of the year. Students are told that they will be awarded points when they pay attention to the class. Points are deducted from students' homeworks when they show up with no books and notebooks. Class subjects are kept related to the real life in order to keep students interested. If too many students are distracted from the subject, the lecture is told in an interesting manner or the previous lecture is reviewed. If a student is constantly distracted during class, the teacher talks to the student personally, in order to find out what the problem is. If the teacher can't solve the problem and the negative behavior remains, parents of the students are called in and students are sent to guidance counseling. Students who use their cellphones are relived from their phones and it's not given back until the end of the year.

Teacher 2: Students who constantly talk during class are given a warning. Eye contact is established with the loud student, if the noise doesn't stop, the student is approached. Students who get up and talk without leave are warned using their names. A student who behaves disrespectfully to the teacher, disregards the teacher and persists on behaving undesirably despite all efforts is sent to the disciplinary board.

Teacher 3: A student who is constantly tardy is sent to the principle or the vice principle. Eye contact is established with the student who speaks rudely to classmates, they are warned verbally and the student is informed that their behavior should be improved, otherwise their parents shall be called in to the school. A student who constantly asks to go out isn't allowed to go out and is reminded that they should attend to their personal needs during breaks.

Results acquired from this research shows that there are many effective methods for dealing with undesirable student behaviors when they are encountered. These methods consist of motivating students, helping students like school and enriching social activities. On the other hand, existing disciplinary actions, scolding and giving advise are also among methods that teachers use for dealing with undesirable behaviors. Various researches have shown that punishments don't have the necessary affect on changing such behaviors [13]. Using methods such as strict disciplinary while dealing with these behaviors in schools by teachers tend to make matters even worse. Apathy and hostility towards school and teachers are among negative results of punishments. On the other 
hand, teachers talking to the child personally and directing the child to guidance services after sharing their observations when negative student behaviors are encountered are preferred more commonly [13]. Another finding of this research is that the majority of teachers have an important role in dealing with negative student behaviors. Teachers have talked to students about the importance of being a good role model. Pubescent middle school students truly need healthy role models to achieve development of their identities. According to research findings, although most of the teachers believe that they have an important role in preventing undesirable behaviors, half of the teachers don't believe their qualifications are well enough to manage them. The fact that teachers react in less than competent methods to undesired student behaviors may indicate that they aren't intellectually equipped well enough [12]. Furthermore, the teachers who participated in this research expressed that they needed on the job training in order to improve their skills especially on dealing with adolescence period issues, class management and communication. It is believed that it is crucial to address teachers' lack of knowledge in the aforementioned issues. Planning on the job training programs in accordance with teachers' needs is of great importance for teachers to increase their competence. Also, it is believed that group guidance works aimed for teachers will increase their skills in dealing with student behaviors. For example, it is determined that a group guidance program aimed for teachers, developed by [14] in Ankara positively changed teachers' discipline attitudes. So, it is believed that increasing the numbers of such programs is important. Another noteworthy finding in this research is that although teachers express that they have the most trouble in their academic lives, they didn't mention teaching environment and activities for arranging materials. It is probable that they didn't mention it because they find themselves to be competent about it. In order to clear up the issue, it is thought that a separate study plan focusing on teachers' level of academic competence and students' perception of negative behaviors is important [15].

\section{Discussion and Recommendations}

When other studies in this literature are analyzed, undesired student behaviors are similar to the undesired student behaviors defined in this study. [16] have determined in their study that "among negative student behavior coping methods, teachers choose most commonly, respectively from more common to less common, talking to students privately, verbal warning, reminding rules, talking to parents and saying that they are upset because of the behavior." [17] has reported that among most common undesired student behavior that teachers encounter are "seeking attention in the classroom, talking without asking permission and loudly, fighting, threatening classmates, inappropriate language and constant laughing" and the most common coping strategy for teacher to be verbal warning and eye contact. [18] has expressed that the most common reaction to undesired student behaviors are; "revising the behavior", "expressing 
the correct behavior and its positive outcome," "contacting school administration," "calling parents," "utilizing guidance services," "physical punishment." [19] determined in her research that among the most common undesired student behaviors are, "talking without permission, making noise, not paying attention to class, showing up without homeworks, giving nicknames and inappropriate language." She determined that the most common methods that teachers are "verbal warning, talking to the student in person, reminding the rules and appointing responsibility." [20] determined that in his study that among the most common undesired student behavior coping methods are, "communicating respectfully, being just, appointing responsibility, explaining in a simple and clear manner."

Teachers also have used long term methods for preventing undesired student behaviors [15]. It was observed in the research that when teachers attempt to manage the problems from undesired student behaviors but the problem seemed to get worse, they send the student to the principle or the guidance counselor [15].

In the scope of this study, it was aimed to determine the most common undesired student behaviors and what kind of strategies are utilized to cope with them.

While the strategies that middle school teachers utilize to cope with undesired student behaviors at the end of this research, ceratin limitations applies to the research. One of such is the fact that only teachers who teach in the Güzelyurt area are interviewed. So, it is believed that for similar studies to be conducted regarding teachers from a wider range of sample groups and different types of schools is important in order to be able to generalize the results of this research. Another limitation to this research is that the question of "What are the strategies you utilize in order to change undesired behaviors?" were asked in a general meaning. In conclusion, the most common of undesired behaviors is students talking among each other during class. Teachers establish eye contact with students who make noise, ask questions to the student about the subject in hand aiming to attract the student's attention, warn the student by calling them by their names. It can be observed that teachers aim to suppress the undesired behavior without interrupting the class or distracting other students. According to this research, the most common method teachers utilize in order to eliminate the undesired behavior is verbal warning.

It can be said that instead of tolerating methods such as approaching the student, touching, warning discreetly, establishing eye contact are utilized less often than reminding the rules, warning publicly, asking questions. While dealing with issues concerning maintaining order in classroom by correcting wrong behaviors and improving them, teachers or other students being a role model may be effective in altering behavior. Doing so, sustainability in exhibiting desired behavior, students' adopting the expected behavior quicker, improving students' academic outcome, consistency of these behaviors may be 
achieved. However, the fact that teachers lack the quality of being a role model in altering behaviors and don't exhibit the desired behaviors often is a limitation to practicing such methods.

Teachers utilizing the methods such as reminding the rules, warning publicly, aiming to address the behavior by asking questions very often may hinder learning activities or interrupt them completely. Teachers utilizing methods that will not affect students' attention to the class, that are based on tolerance such as aiming to establish eye contact, touching, approaching, ignoring and talking to the student out of the classroom and address their behavioral problems in order to solve them primarily, may be effective as well as not affecting teaching process negatively.

It will be beneficial if the teacher centered system in which teachers are the rule makers; the perception of teachers' role as maintaining the order in the classroom and if teachers followed the publications that focus on students' needs and stages of their development that encourage a student centered, free and flexible system.

Also in a similar scope, it is believed that while asking teacher about the strategies they utilize while dealing with negative student behaviors, more data may be obtained if the classes are observed on the matter. Finally, if teachers' reaction towards negative student behavior depend on criteria such as teachers' job experience, genders, perception on competence, etc. So, it is advised concerning new researches that variables that are thought to affect teachers' reactions are included withing the aims of such research.

\section{References}

[1] Sarıtaş, M. (2006) Öğretmen Adaylarının Değerlendirmelerine Göre Sınıfta İstenmeyen Öğrenci Davranışlarını Değiştirmek ve Düzeltmek Amacıyla Yararlanılan Stratejiler. Uludağ Üniversitesi Eğitim Fakültesi.

[2] Başar, H. (2006) Sınıf yönetimi (13 Basım). Anı Yayıncllık, Ankara.

[3] Wilks, R. (1996) Classroom Management in Primary Schools: A Review of the Literature. Behaviour Change, 13, 20-32. https://doi.org/10.1017/S0813483900003922

[4] Aydın, A. (2013) Sınıf Yönetimi. Pegem Akademi, Baskı, 16.

[5] Akar, H., Tor, D., Tantekin-Erden, F. and Şahin, İ.T. (2010) Öğretmenlerin Sinıf Yönetimi Yaklaşımları ve Deneyimlerinin İncelenmesi. İlköğretim Online, 9/2, 792806.

[6] Okutan, M. (2006) Sınıf Yönetiminde Örnek Olaylar. Öğreti Yayınevi, Ankara.

[7] Çakmak, M., Kayabaşı, Y. and Ercan, L. (2008) Öğretmen Adaylarının Sınıf Yönetimi Stratejilerine Yönelik Görüssleri. Hacettepe Üniversitesi Eğitim Fakültesi Dergisi, 35, 53-64.

[8] Korkmaz, İ. (2002) Sınıf Yönetimi. 2 baskı, Pegem Yayıncılık, Ankara.

[9] Çelik, V. (2005) Sınıf Yönetimi. 3 baskı, Nobel Yayın Dağııım, Ankara.

[10] Çetin, B. (2013) Sınıfta İstenmeyen Öğrenci Davranışlarıyla İlgili Sınıf Öğretmenlerinin Karşılaştıkları Sorunlar ve Çözüm Önerileri. Ahi Evran Üniversitesi Kırşehir Eğitim Fakültesi Dergisi (KEFAD) cilt, 14, 1. 
[11] Kaya, Z. (2014) Sınıf Yönetimi. Pegem Akademi Yayıncılık, Ankara.

[12] Karasar, N. (2009) Bilimsel Araştırma Yöntemleri. Nobel Yayınları, Ankara.

[13] Siyez, D.M. (2009) Liselerde Görev Yapan Öğretmenlerin İstenmeyen Öğrenci Davranışlarına Yönelik Algıları ve Tepkileri. Pamukkale Üniversitesi Eğitim Fakültesi Dergisi, 25.

[14] Şimşek, Ö.F. (2004) Bir grup rehberliği programının öğretmenlerin disiplin anlayışına etkisi. Ankara Üniversitesi Eğitim Bilimleri Fakültesi Dergisi, 37, 41-59. https://doi.org/10.1501/Egifak_0000000095

[15] Çankaya, İ. (2011) Sınıf Öğretmenlerinin Karşılaştıkları İstenmeyen Öğrenci Davranışları ve Bu Davranışlarla Başa Çıkma Yolları. International Periodical for the Languages, Liretatüre and History of Turkish or Turkic, 6, 307.

[16] Kılıç, Z.Ö. (2009) İlköğretim Öğretmenlerinin Duygusal Zeka Düzeyleriyle Öğrencilerin İstenmeyen Davranışlarını Algılamaları ve Başa Çıkma Yöntemleri Arasındaki İlişki. Yayımlanmamış Doktora Tezi, Marmara Üniversitesi Eğitim Bilimleri Enstitüsü, İstanbul.

[17] Özer, G. (2009) Öğretmen adaylarının sınıf içinde gözlemledikleri istenmeyen öğrenci davranışları ve bu davranışlarla bas etmede kullanılabilecek stratejilere ilişkin görüşleri. Yayımlanmamış Yüksek Lisans Tezi, Zonguldak Karaelmas Üniversitesi Sosyal Bilimler Enstitüsü, Zonguldak.

[18] Beşdok, D. (2007) Ortaöğretim Öğretmen/erinin Sınıf Yönetiminde Karşılaştıkları istenmeyen Öğrenci Davranışlarını Önleyebilme Yeterliklerinin Değerlendirilmesi (Kayseri Iii Örneği) Yüksek Lisans Tezi. Erciyes Üniversitesi Sosyal Bilimler Enstitüsü, Kayseri.

[19] Tolunay, A. (2008) Sınıf Öğretmenlerinin Sınıfta Karşılaştıkları İstenmeyen Öğrenci Davranışları ve Bu Davranışlara Karşı Kullandıkları Baş Etme Yöntemleri. Uludağ Üniversitesi Sosyal Bilimler Enstitüsü, Yayınlanmamış Yüksek Lisans Tezi, Bursa.

[20] Sipahioğlu, E. (2008) İlköğretim I. kademede sınıf içi istenmeyen öğrenci davranışları ve çözüm önerileri (Narlıdere İlçesi Örneği) Yayımlanmamış Yüksek Lisans Tezi. Beykent Üniversitesi Sosyal Bilimler Enstitüsü, İstanbul.

Submit or recommend next manuscript to OALib Journal and we will provide best service for you:

- Publication frequency: Monthly

- 9 subject areas of science, technology and medicine

- Fair and rigorous peer-review system

- Fast publication process

- Article promotion in various social networking sites (LinkedIn, Facebook, Twitter, etc.)

- Maximum dissemination of your research work

Submit Your Paper Online: Click Here to Submit

Or Contact service@oalib.com 